
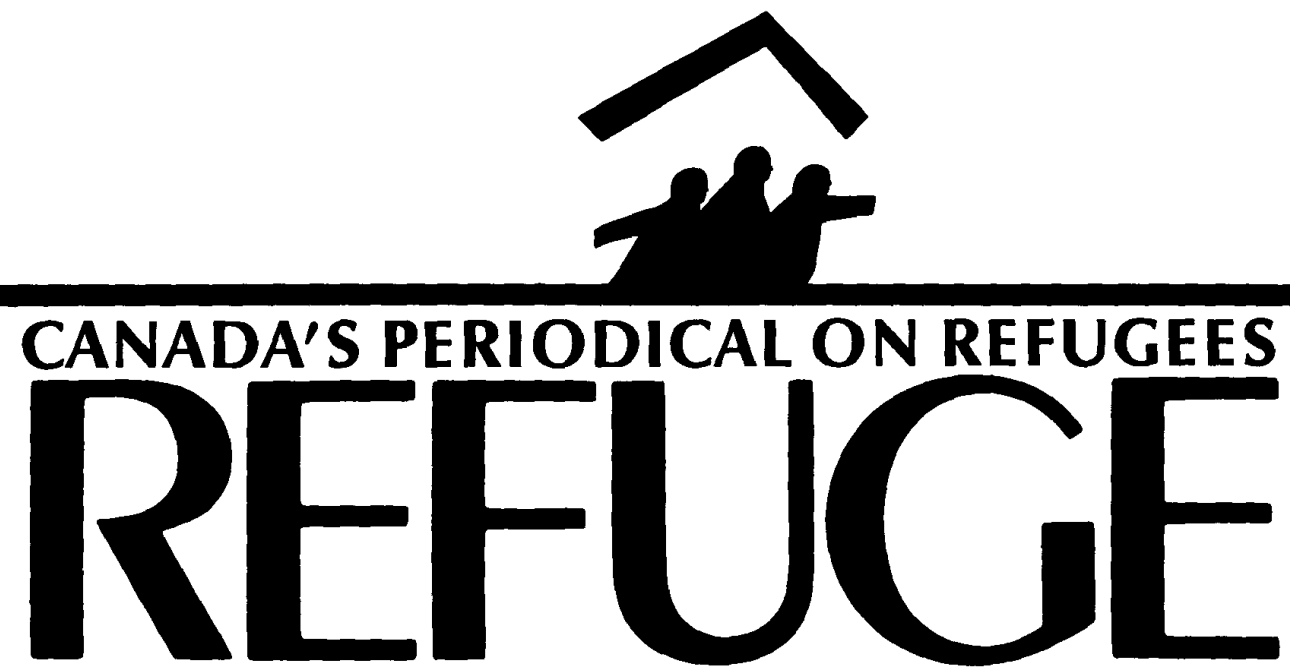

Vol. 5 No. 2

\title{
The Jewish Refugee Experience
}

The contributions in this issue stem primarily from Refugees in Canada The Jewish Experience: A Case Study, a symposium organized by the Jewish Student Federation and the Refugee Documentation Project at York University on November 11-14, 1985. Its purpose was to examine, through a series of lectures and panel discussions on Jewish refugees, the complexities of the refugee phenomenon.

In a forum about refugees, prime consideration is usually given to resettlement challenges: What difficulties do refugees have to face? What kind of help are they able to receive? How do they adapt to a new environment? These questions remained key issues at the symposium. But the event was also designed to study a specific refugee experience within a broader context. This was done both in terms of the general historical, political, cultural, racial and economic factors accounting for Jewish refugee migration, and against the specific background provided by Canada's uninspired past immigration policies and attitudes towards Jewish refugees.

continued on p. 2

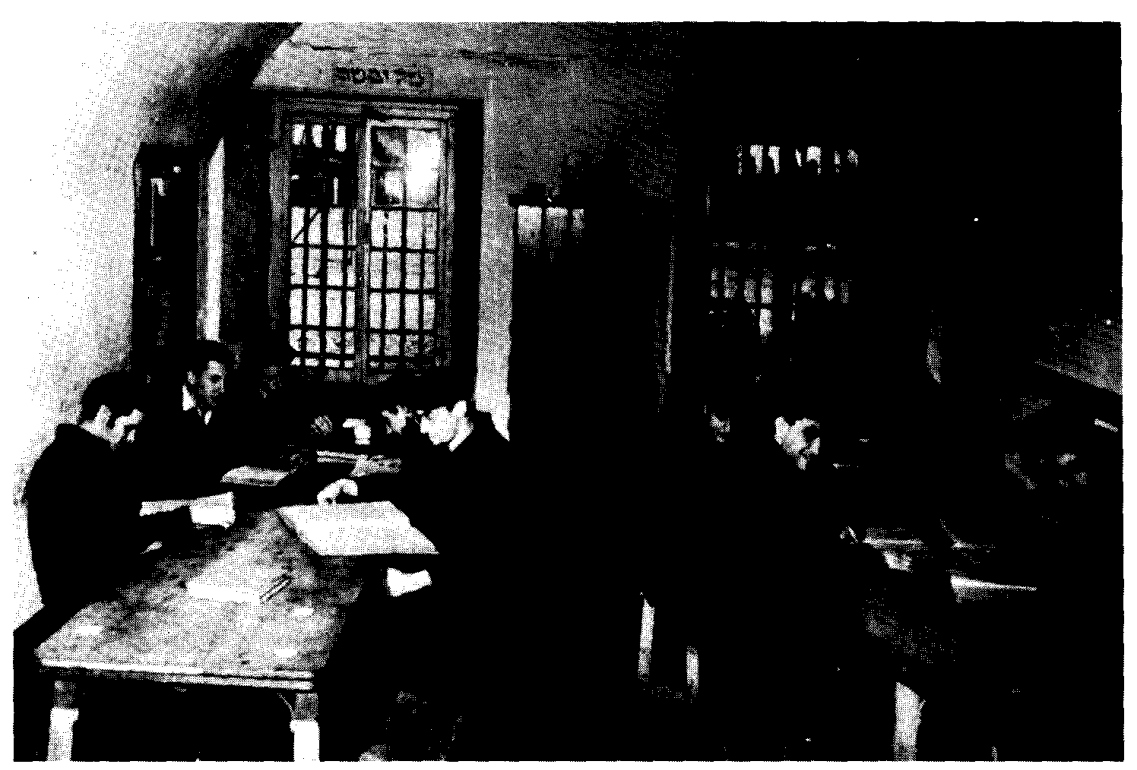

Yeshiva students in Camp I, Isle aux Noix (Fort Lennox), Quebec. (Courtesy of Rabbi Erwin Schild).

IN THIS ISSUE:

Population Movements in Eastern Europe and the

"Final Solution" by Michael R. Marrus

page 3

Racism in Canadian Immigration Policy by David Matas

page 8

North America and the Jewish Refugee Crisis

by Irving Abella

page 10

"Refugee!" The Adjustment of Jewish Refugees from Nazism to Canadian Life by Paula J. Draper

page 15 


\section{Opening Remarks Harry Arthurs, President of York University}

The past will always remain an inexhaustible source of lessons to improve the future. The Refugees in Canada symposium attempted to educate the general public about the plight of refugees by exploring some critical aspects of Jewish refugee migration. In the process, Refugees in Canada also strived to deal with experiences which could serve as examples or guidelines to other recent refugee communities eager to find in Canada a better place to live. In this respect the present issue attempts to preserve the spirit of the symposium.

Alex Zisman

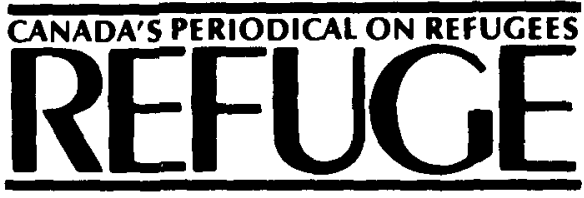

c/o Refugee Documentation Project, York University 4700 Keele Street, North York, Ontario M3J 1P3

\section{Editor:}

Howard Adelman

Feature Editor:

Alex Zisman

Managing Editor:

Leslie Rider

Refuge is dedicated to encouraging assistance to refugees, by providing a forum for sharing information and opinion on Canadian and international issues pertaining to refugees. It is published four times a year by the Refugee Documentation Project. It is a non-profit, independent periodical supported by private donations and by subscriptions. It is a forum for discussion, and the views expressed do not necessarily reflect those of its funders or staff.

All material in Refuge may be reproduced without permission unless copyrighted or otherwise indicated. Credit should be given to the author or source if named.

Subscription rates for one year are $\$ 20.00$. Please enclose payment with your order No discounts can be given for American funds because of bank charges for foreign cheques.

Logo design:

Dreadnaught Cooperative Inc., Toronto

Second Class Mail Registration No. 5512 ISSN 0229-5113
I would like to welcome you all to York University and, on behalf of the University, to say that we are very honoured and pleased that this discussion will be going on this week. Amongst the adjectives that people use to describe the Jewish community, at least two recur frequently: one of those is "scholarship" and the other is "a passion for justice". Scholarship is well represented by our distinguished moderator, Howard Adelman, and our two speakers, Michael Marrus and Irving Abella, both of whom have earned important reputations not just within the Jewish community but throughout the entire Canadian and indeed international academic community. They are two leading figures in the writing of contemporary history and we are very pleased to have both of them here this evening.

The other half of my short list of characteristics of the Jewish community, the concern for social justice, I hope will manifest itself as discussions progress over the next few days. When refugees arrive, of course, their first start must necessarily be to establish themselves, to make a new home for themselves, to make a new life for themselves. And at the juncture it seems to me they have two options, either to continue to be preoccupied with their own condition or fate or to reflect upon the experience that they have just gone through and to take out of it some large lessons that may have application for others. I think, historically at least, to the credit of the
Jewish community, that it has always adopted the second of those two options. It has tended to translate its own refugee experience into a series of more universal concerns for the fate of people who themselves are experiencing oppression, who have to uproot themselves and translate themselves into a new country and a new life.

The expericence of doing that, as the earlier wave of Jewish refugees found, was not always an easy one. Countries that people went to - and this country in particular - were not as open, not as hospitable, not as fair, not as just as they ought to have been if they had even lived up to their own ideals. And this sense of how countries fail to live up to their ideals, and fail to appropriately greet and treat people who have come to live in that country, sensitized the Jewish community, certainly in the early stages of its history here. There was a need to make sure that there was a just society and one which would be welcoming and supportive of other groups as they arrived.

I hope that that second theme will be explored tonight and on subsequent occasions throughout this series, as we learn how the particular gets translated into the universal, and especially how the Jewish experience comes to have real salience for other groups that come a little later in time. I am sure that these will be most interesting speeches and I certainly look forward with you to hearing them.

The symposium Refugees in Canada - The Jewish Experience: A Case Study was sponsored by:

B'nai Brith Hillel Foundations of Canada; Immigrant Settlement and Adaptation Programme, Canada Employment and Immigration Commission; Israel Discount Bank of Canada; Jewish Immigrant Aid Service (JIAS); Toronto Jewish Congress Endowment Fund.

York University: Atkinson College Students' Association (ACSA); Calumet College General Meeting; Communications Department; Council of the York Student Federation (CYSF); Dean of the Faculty of Arts; Dean of the Faculty of Education; Dean of the Faculty of Fine Arts; Dean of the Faculty of Graduate Studies; Department of Film; Department of Political Science; Department of Sociology; Division of Social Science; Founders College Student Council; Graduate Programme in Social and Political Thought; Graduate Students' Association (GSA); Jewish Student Federation (JSF); Master of Atkinson College; Master of McLaughlin College; Master of Winters College; President; Provost; Refugee Documentation Project; Robarts Centre for Canadian Studies; Winters College Council; York International. 